\title{
The use of Telenomus remus (Nixon, 1937) (Hymenoptera: Scelionidae) in the management of Spodoptera spp.: potential, challenges and major benefits
}

\author{
Yelitza Coromoto Colmenarez ${ }^{1}$, Dirk Babendreier ${ }^{2}$, Francisco Ramón Ferrer Wurst ${ }^{3}$, \\ Carlos Luis Vásquez-Freytez ${ }^{4}$ and Adeney de Freitas Bueno ${ }^{5^{*}}$ (1)
}

\begin{abstract}
Spodoptera frugiperda (Smith, 1797) (Lepidoptera: Noctuidae), also known as fall armyworm (FAW) is a polyphagous pest which can cause significant losses and is considered a global threat to different crops and a risk to food security. Currently, in maize, the pest is predominantly controlled by pesticides or transgenic events. However, the use of biological control agents is considered the most sustainable and preferred method of control, providing high effectiveness. Among the various natural enemies reported for FAW, the egg parasitoid Telenomus remus has gained most interest, and has been mass released against FAW in the Americas for many years. In addition to FAW, other armyworms of the genus Spodoptera often cause high crop damage and may be controlled using T. remus. Among other important aspects, this paper presents a review on T. remus mass rearing techniques, estimated costs of mass production, and release strategies. Due to the recent invasion of FAW in Africa, Asia, and Australia T. remus provides good opportunities for the establishment of an augmentative biological control program, reinforcing sustainable production of major crops such as maize in affected countries.
\end{abstract}

\section{Introduction}

The genus Spodoptera Guenée (1852) comprises numerous lepidopteran moths, such as Spodoptera frugiperda (Smith, 1797), Spodoptera eridania (Stoll, 1782) and Spodoptera cosmioides (Walker, 1858) (Lepidoptera: Noctuidae) which are known for their economic importance as pests of several crops worldwide (Brown and Dewhurst 1975; Panizzi et al. 2012; Bortolotto et al. 2015). The fall armyworm (FAW), S. frugiperda, is one of the most devastating pests in the genus. It feeds on leaves, stem and reproductive parts of a wide range of host plants,

\footnotetext{
*Correspondence: adeney.bueno@embrapa.br

${ }^{5}$ Embrapa Soja, Rodovia Carlos João Strass - Distrito de Warta, Londrina, Paraná 86001-970, Brazil
}

Full list of author information is available at the end of the article including common beans, cotton, maize, rice, sorghum, soybean, and vegetables among others (Pogue 2002; Nagoshi 2009; Bueno et al. 2011; Silva et al. 2017; Sagar et al. 2020). Not only is FAW a global threat to different crops but also a risk to food security (Rwomushana et al. 2018; Sagar et al. 2020). Currently, growers frequently apply synthetic insecticides to control Spodoptera spp. However, the overuse of insecticides has triggered some negative side-effects (Song and Swinton 2009) such as the selection of resistant pest populations (Diez-Rodriguez and Omoto 2001; Carvalho et al. 2013), the reduction of biological control agents (Torres and Bueno 2018), or outbreaks of secondary pests (Bueno et al. 2021). Therefore, a more sustainable Spodoptera spp. management is of high interest for millions of farmers globally. 
Integrated Pest Management (IPM) is defined as the combination of different control methods, implemented jointly to keep insect pest populations below the level of economic damage, considering economic, ecological and social criteria (Norris et al. 2002). Along with cultural control measures, biological control plays an important role within the IPM approach as an environment-friendly and sustainable pest management strategy. In addition to classical biological control and conservation biological control, augmentative biological control has been increasingly accepted by growers and is currently being applied on more than 30 million ha worldwide (van Lenteren et al. 2018).

Egg parasitoids are one of the most important groups of biological control agents used in augmentative biological control due to their action on early pest stages before any damage occurs to the crop (Parra and Coelho Jr 2019). Therefore, augmentative biological control employing egg parasitoids has been increasingly used in Latin America to fight pests damaging a number of crops (van Lenteren and Bueno 2003; van Lenteren et al. 2018). The egg parasitoid Telenomus remus Nixon, 1937 (Hymenoptera: Scelionidae) is native to peninsular Malaysia and Papua New Guinea (Wengrat et al. 2021) and has been released against various pest species of the genus Spodoptera (Pomari et al. 2012; Bueno et al. 2008; 2010; Ferrer 2001; 2021). The biology and ecology of this egg parasitoid has been studied in the past and reviewed by Cave (2000). In addition to its high fecundity, T. remus is especially noteworthy for its effective action on eggs of Spodoptera spp. in superposed layers, even parasitizing eggs located in the inner layers of the egg mass (Figueiredo et al. 1999; Bueno et al. 2008) (Fig. 1). Furthermore, T. remus has high dispersal (Pomari-Fernandes et al. 2018) and host search capacities (Pomari et al. 2013a) underlining its potential for augmentative biological control programs. Noteworthy, T. remus has been released against FAW in maize on a large scale (several thousands of ha) during the 1990s in Venezuela as part of an IPM program and on slightly smaller scale until recently (Ferrer 2001; 2021). These releases have resulted in an overall reduction in insecticide use against FAW of between 49 and $80 \%$. Telenomus remus has achieved up to $90 \%$ of FAW egg parasitism after releases (Ferrer 2021; Hernández et al. 1989).

However, a lot of information collected and experiences gained during the history of T. remus in biological control programs is neither published in peer reviewed journals and/or not available in English. This is of particular concern as recently there is increasing interest in this biological control agent also in the newly invaded regions, i.e. Africa, Asia and Australia (e.g. Kenis et al. 2019; Agboyi et al. 2021). We here thus review the available literature on $T$. remus, with a focus on the substantial practical experiences gained in Latin America on the management of FAW and other species of the genus Spodoptera, aiming to provide better guidance for improved and potentially global application of $T$. remus in integrated pest management programs against FAW. This includes important aspects such as mass production of T. remus, parasitoid release strategies, field use and its compatibility with chemical insecticides among others.

\section{Telenomus remus mass rearing}

Mass rearing of any augmentative biological control agent is a critical step to achieve success (Parra 2010). It has been studied for $T$. remus extensively for more than 40 years, reflecting not only the importance of this egg parasitoid in biocontrol attempts but also the major difficulties and challenges this species poses. Theoretically, there are three different ways in which $T$. remus could be reared: (i) on the natural host, (ii) on factitious hosts (both in vivo) and (iii) on an artificial diet (in vitro). To the best of our knowledge, only in vivo $T$. remus rearing has been used so far with both advantages and disadvantages comparing natural and factitious hosts.

Telenomus remus rearing started in India using eggs of the natural host Spodoptera litura (Fabricius, 1775) (Lepidoptera: Noctuidae) first (Joshi et al. 1976; Gupta and Pawar 1985), and then eggs of the factitious hosts Agrotis biconica Kollar (Lepidoptera: Noctuidae) (Gautum and Gupta 1994) and Corcyra cephalonica Stainton (Lepidoptera: Pyralidae) (Kumar et al. 1986).

Using FAW eggs (natural host) for T. remus rearing might pose a problem due to cannibalism among FAW larvae, which obviously is a major obstacle in any rearing. This might be overcome by switching artificial diet for FAW rearing. Ferrer (2021) reported on the mass production of $T$. remus on FAW eggs in which this host is reared with a diet based on spurge or castor leaves (Ricinus communis). The author considered this rearing method as a cost-effective one to be used on smaller mass production units, especially because low cannibalism is observed among FAW larvae, optimizing host production. According to Glober (2019), although larvae reared on castor oil plants are still cannibalistic, the extent of cannibalism is lower. The same author highlighted that this is probably due to the influence of castor leaves on the microbial midgut community structure and its composition making larvae emit chemical compounds that could repel conspecific larvae and in turn suppress cannibalistic behaviour. Alternatively, eggs of $S$. litura (natural, non-cannibalistic host) or a factitious host could be used. In addition, Gautum (1986) suggested the use of Agrotis spp. eggs as a factitious host for one generation to improve the biological efficacy of $T$. remus, because 


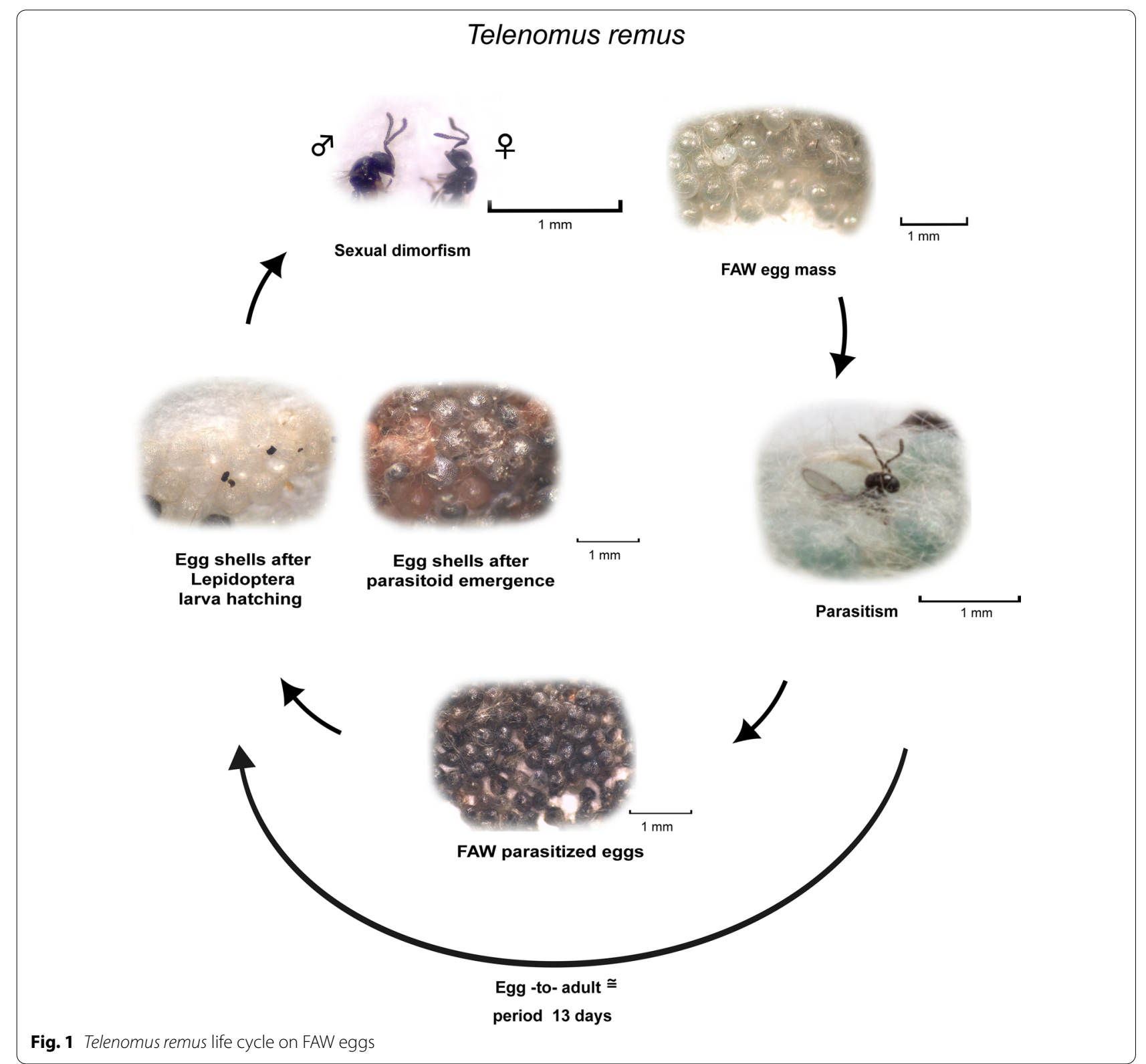

adults reared in Agrotis spp. eggs are bigger, live longer and are more fecund than adults reared in Spodoptera spp. eggs.

Another factitious host that can be used for T. remus rearing is $C$. cephalonica, which can be produced at low costs and has been already used for rearing other egg parasitoids such as Trichogramma spp. (Babendreier et al. 2020a). However, eggs of C. cephalonica are considerably smaller than Spodoptera spp. ones. Consequently, $T$. remus reared from these factious hosts are also smaller and live shorter than adults reared in FAW eggs (Kumar et al. 1986; Queiroz et al. 2017a). Moreover, lower lifetime parasitism on FAW eggs was recorded for T. remus reared on C. cephalonica eggs (Queiroz et al. 2017a) compared to T. remus reared on FAW eggs (Pomari et al. 2013b). Nevertheless, T. remus reared on C. cephalonica eggs does not lose its capacity of parasitizing eggs of Spodoptera spp. even in superposed layers and its flight abilities measured in laboratory trials (Pomari-Fernandes et al. 2016) or its dispersal capacities under field conditions (Pomari-Fernandes et al. 2018). The lower lifetime fecundity of course is still of concern but may be solved through the release of higher number of parasitoids. Another advantage of C. cephalonica eggs is that they can be stored for up to 21 days at $10{ }^{\circ} \mathrm{C}$ for subsequent parasitism by $T$. remus while Spodoptera spp. eggs can hardly 
be stored before being offered for parasitism (Queiroz et al. 2017b). Despite these promising findings, there are also cases of failures for T. remus rearing on C. cephalonica eggs (D. Babendreier, personal communication). Moreover, as far as we know, C. cephalonica has only been used for the production of $T$. remus for research purposes. So far, no mass rearing of $T$. remus using $C$. cephalonica has been established on a commercial scale, which raises concerns about the field effectiveness of $C$. cephalonica-reared wasps and overall cost-effectiveness. Therefore, underlying reasons regarding success vs failure of rearing T. remus on C. cephalonica and whether this may be due to different parasitoid strains or rearing protocols adopted, still deserves more research in near future.

Irrespective of the rearing host, control of environmental conditions is highly relevant. Overall, a moisture regime of $80 \%$ (Pomari-Fernandes et al. 2014) and a temperature range from 22 to $28{ }^{\circ} \mathrm{C}$ (Pomari et al. 2012) are reported as optimal rearing conditions. Adults should be fed preferably with honey offered as small droplets spread over adult cage walls. To establish the correct host-parasitoid ratio is also crucial since it directly impacts quality parameters, in particularly the sex ratio (van Welzen and Waage 1987). Considering that T. remus parasitism capacity ranges from 60 (Pomari et al. 2013b) to around 82 eggs (Morales et al. 2000) during the first $24 \mathrm{~h}$ of parasitism and then is reduced to less than 30 eggs on the second day and less than 20 eggs on the following days (Pomari et al. 2013b), it might be suggested that the ideal host-parasitoid ratio should be around 100 eggs/female on the first day of parasitism which later can be reduced to 36 and 24 eggs/female on the second and third day of parasitism, respectively. The proportion of around 20 eggs/parasitoid female should be kept until the fifth or sixth day of parasitism when the remaining adults alive may be discarded. The first day of parasitism is $48 \mathrm{~h}$ after the first adults had started to emerge because those first adults emerging are males (Cave 2000). These recommendations may need to be adapted to the specific conditions in a given rearing facility and still be tested in massive rearing conditions since they have been adopted so far only in laboratory rearing in small scales or research purposes.

As with all mass rearing facilities, it is very important to implement quality control measures to observe and potentially address any issues. One challenging aspect is the risk of parasitoid fitness losses in long-term production systems, as it is known that $T$. remus foraging and flying abilities can be reduced when reared for many generations (Naranjo-Guevara et al. 2020). As possible solutions to this problem, the establishment of varying rearing conditions (different regimes of light, temperature, and humidity, for example), and the introduction of wild individuals (periodically) into the laboratory rearing have been suggested. The refreshment of the insect colony with individuals collected from natural populations is likely the most effective measure but should be done with caution since taxonomic knowledge is required to avoid colony contamination with other parasitoid species (Wengrat et al. 2021) or fungal and bacterial pathogens from the field, among other possible negative issues.

Currently, T. remus is being reared in different countries mainly in Latin American and Africa, for commercial and research purposes at different scales. In Peru, mass production of $T$. remus has been conducted around the country by private companies facilitating the use of this natural enemy against Spodoptera spp. (Mujica and Whu 2020) on 37 ha of maize and vegetables. Another interesting example from Peru is the commercialization of $T$. remus by a government laboratory which produced T. remus on FAW eggs as part of the Chavimochic project implemented in the Libertad Department by the Agricultural Development Department. Farmers could buy the parasitoids at $20 \mathrm{PEN} / 1000$ parasitoids, totalling 60-160 PEN/ha (around 15-41 USD/ha) (Gobierno de la Liber$\operatorname{tad} 2012$ ).

Since 2005, three laboratories run by the Venezuelan government have been rearing $T$. remus for inundative releases (Vásquez et al. 2020) offering T. remus to farmers for free or very much reduced prices. This differs from the previous work conducted by the private company named "Servicio Biologico" (ServBio) where parasitoids of $T$. remus were commercialized, establishing a sustainable business model in the 1990s (Ferrer 2001, 2021). It is considered that the success for the high production and adoption of $T$. remus in Venezuela against FAW in maize during more than 10 years (1989 to 1999) was not only due to the strong linkages between biological control producers and farmers associations (technology transfer services) but also to the low costs of T. remus (which varied from 7.5 to 17.5 US\$/ha per release) and most importantly, due to the grower's savings of 19.3 to 36.3 USD/ ha when the egg parasitoid was used as part of the IPM package (Ferrer 2001). In addition to the use of T. remus in Venezuela, the adoption of the whole IPM practices allowed the reduction of $80 \%$ of the insecticide load commonly used in maize production with both financial and environmental benefits for growers (Ferrer 2001, 2021).

In addition, once Venezuelan farmers realized the importance of $T$. remus as biocontrol agent, they started their own mass rearing in a small scale, initiating the piloting process with a champion farmer who used $R$. communis for the mass production of FAW, having low costs for $T$. remus mass rearing. This champion farmer 
popularized the use of $T$. remus against FAW, as he used to promote its use and sell T. remus to local producers (Ferrer 2021). Thus, several field trials were carried out by SERVBIO (Servicios Biológicos C.A.) with the purpose of studying the dispersion, effectiveness and economic results in various states of Venezuela (Ferrer 2001; Fuentes et al. 2012), and in consequence implementations of biological control and IPM programs in 1960 ha in four Venezuelan states allowed to obtain $49 \%$ savings in insecticide use compared to the cost of a program without IPM application (Ferrer 2021).

\section{Cost of mass production}

Production costs of $T$. remus reported in the literature have a large range of variation, which is possibly related to differences found in insect colony size, host used, labour costs, level of mechanization, among several other issues that can dramatically impact final results. Certainly, one of the costly factors and often the limiting one in commercial production of T. remus is the labour costs (Román Suárez 1998), which can greatly vary among countries and even regions.

According to Santos-Erazo (1998) and Linares (1998), the rearing costs of producing 1000 individuals of $T$. remus using FAW eggs was 0.5 and 2.2 USD, respectively. Vieira et al. (2017) reported an even cheaper value in Brazil of 0.4 USD to produce 1000 T. remus using FAW eggs, considering as total cost only the effective operating expenses incurred based on diet, labour, energy consumed by existing equipment, expenses related to other materials, and costs related to depreciation of equipment and furniture (missing only the new equipment and building costs).

Generally, total costs for producing T. remus are highly influenced by the cost of producing FAW egg masses which can reach up to $84 \%$ of total costs (Santos-Erazo 1998). Thus, crucial attention should be given to FAW rearing diets due to its high cost and the cannibalistic habit of S. frugiperda larvae (Martínez-Martínez et al. 2015). As mentioned in the previous section, $R$. communis leaves have been used as food to rear Spodoptera spp. in order to reduce diet costs but also cannibalism among larvae and therefore overall FAW production costs (Cabezas et al. 2013). Martínez-Martínez et al. (2015) presented $R$. communis as an alternative to mass production of FAW, reporting similar survival of larvae and pupae when fed with corn leaves or $R$. communis. Despite promising results when using $R$. communis for FAW mass production in Venezuela (Ferrer 2021), further studies are necessary, also because several toxic substances have been reported in this plant species, especially when the extracts are coming from the seeds (Ramos-Lopez et al. 2010). Alternatively, an investigation carried out at CIMMYT, Mexico, showed that multicellular grids filled with diet are more effective to increase $T$. remus production, as it allows to increase the production of S. frugiperda compared to the traditional 1-oz cap system, which could help to reduce the costs of mass production (Mihn 1984).

More recently, the production costs of T. remus reared on FAW eggs were updated for a Venezuelan commercial setting based on the production of high-quality parasitoids sufficient for 4,000 ha of maize at 8,000 wasps/ha

Table 1 Operational costs (June 2021) for mass rearing of T. remus considering the need for construction of a facility (32 mio T. remus to be released which requires 35.2 mio parasitoids to be produced per crop season) in Yaracuy State, Venezuela

\begin{tabular}{|c|c|}
\hline Item & Cost (USD) \\
\hline Facilities construction (considering a 20-year depreciation) (f) & 4500 \\
\hline Equipment (considering a 4-year depreciation)* (f) & 6254 \\
\hline Direct inputs (Diet) (v) & 9727 \\
\hline Direct material (plastic containers, consumables) (v) & 5235 \\
\hline General supplies and materials (electricity, water, taxes)* $(f, v)$ & 9741 \\
\hline Labour (permanent staff $=6)^{*}(f)$ & 16,000 \\
\hline Labour (non-permanent staff, used only in production peaks $=3$ ) $(\mathrm{v})$ & 3469 \\
\hline Services (maintenance, repair of equipment) ${ }^{*}(f, v)$ & 4163 \\
\hline Transportation* $(f, v)$ & 1500 \\
\hline Total costs & 60,591 \\
\hline Unit cost (T. remus produced) & 1.72 \\
\hline Unit cost (T. remus released) & 1.89 \\
\hline Suggested selling price $30 \%$ of the cost & 2.46 \\
\hline Cost per hectare (8000 parasitoids) & 15.1 \\
\hline
\end{tabular}

*Estimated costs. $f=$ fixed; $v=$ variable; $f v=50 \%$ for each type of cost 
(totalling 32 mio $T$. remus released as recently emerged adults) (F. Ferrer, personal communication, Table 1).

Following the experience in Venezuela with a successful mass production and release of $T$. remus for more than 40 years, the cost of production of $T$. remus per unit of 1000 wasps in June 2021 was 1.89 USD. The total cost per hectare was thus 15.1 USD, based on a release rate of 8000 parasitoids/ha.

\section{Telenomus remus potential, use and field efficiency in different crops}

Telenomus remus parasitism is highly influenced by both temperature (Bueno et al. 2010; 2014; Pomari et al. 2012, 2013b) and humidity (Pomari-Fernandes et al. 2014) under laboratory conditions, indicating that those climatic conditions are crucial for the success of an augmentative biological control program using this parasitoid species in the field. Despite climatic impact over parasitoid performance, it is important to point out that a single $T$. remus female can parasitize 140-220 FAW eggs during her lifetime in laboratory conditions, with similarly high numbers also on other hosts (Table 2) illustrating its high potential to control those lepidopteran pests in the field.

The differences seen in Table 2 might be due to host species as well as differences in relative humidity of the trials. A positive effect of increased humidity on T. remus parasitism has been reported from laboratory studies in S. litura (Gupta and Pawar 1985), Agrotis spinifera (Hubner, 1808) (Lepidoptera: Noctuidae) (Gautum 1986), and C. cephalonica eggs (Pomari-Fernandes et al. 2015). Similar effects of humidity were also reported for Telenomus isis (Polaszek, 1993) (Hymenoptera: Scelionidae) parasitizing coffee borer eggs (Bruce et al. 2009). Despite the clear effect of humidity, it is important to point out that this effect of environmental conditions can differ among host species (Pomari-Fernandes et al. 2014).

Table 2 Lifetime parasitism (number of parasitized eggs/ parasitoid female during its lifetime) of Telenomus remus at $25^{\circ} \mathrm{C}$ on different host eggs

\begin{tabular}{|c|c|c|c|}
\hline Host species & $\begin{array}{l}\text { Lifetime } \\
\text { parasitism }\end{array}$ & $\begin{array}{l}\text { Parental female } \\
\text { longevity (days) }\end{array}$ & References \\
\hline \multirow[t]{2}{*}{$\begin{array}{l}\text { Spodoptera fru- } \\
\text { giperda }\end{array}$} & 140.8 & 8.3 & $\begin{array}{l}\text { Pomari et al. } \\
\text { (2013b) }\end{array}$ \\
\hline & 220.0 & 10.6 & Bueno et al. (2014) \\
\hline $\begin{array}{l}\text { Spodoptera cosmi- } \\
\text { oides }\end{array}$ & 115.3 & 13.1 & $\begin{array}{l}\text { Pomari et al. } \\
\text { (2013b) }\end{array}$ \\
\hline $\begin{array}{l}\text { Spodoptera } \\
\text { eridania }\end{array}$ & 139.5 & 8.0 & $\begin{array}{l}\text { Pomari et al. } \\
(2013 b)\end{array}$ \\
\hline $\begin{array}{l}\text { Anticarsia gem- } \\
\text { matalis }\end{array}$ & 200.5 & 12.4 & Bueno et al. (2014) \\
\hline
\end{tabular}

Different biological features of $T$. remus highlight its high potential for field use in the management of FAW populations. When wasp females were kept fed but without access to host eggs for up to 10 days, there was no reduction in lifetime parasitism compared to females which had access to hosts since emergence (Queiroz et al. 2019). This is a positive characteristic of T. remus for augmentative biological control programs because adults can maintain their potential parasitism and efficiency during periods of low host availability unlike other species of egg parasitoids in which resorption of eggs occurs (Santolamazza-Carbone et al. 2008). It is also a beneficial characteristic for mass rearing as it increases flexibility to match production with the demand for releasing biological control agents in the field and might allow parasitoid storage on a small scale.

The potential to use $T$. remus for pest control in the field was explored first in India where the parasitoid was introduced for classical biological control of Spodoptera spp. in 1963 (Sankaran 1974). Subsequently, T. remus was used in inundative biological control programs against $S$. litura in potato. In this example, the parasitoid were combined with other natural enemies, reducing pest incidence in the crop by $60 \%$ (Ansari et al. 1992).

In the New World, the first introduction of T. remus to control caterpillars from the Spodoptera complex took place during 1971-1972 in Barbados (Caribbean), where levels of parasitism greater than $60 \%$ were recorded in different crops (Cave 2000). In Florida State (USA), more than 660,000 adults of $T$. remus were released for classical biological control of FAW in maize and sorghum from 1975 to 1977 with parasitism levels reaching 43\% (Waddill and Whitcomb 1982).

Later the parasitoid was released and established in several countries of Central America and the Caribbean including Antigua, Dominica, Monserrat, St Kitts, St Vincent and Trinidad \& Tobago. In El Salvador and Nicaragua, T. remus establishment was never detected (at least never reported), probably due to unfavourable environmental conditions at the release sites and/or low quantities released (Cave 2000). As part of an augmentative biological control program in Honduras, T. remus was experimentally released at different rates (from 35,000 to $50,000 \mathrm{wasps} / \mathrm{ha} /$ week to $75,000-105,000 \mathrm{wasps} / \mathrm{ha} /$ week) in maize and sorghum fields during 1991-1994 with observed parasitism rates varying from 20 to $92 \%$ between months, and a lack of clear correlation between parasitism and released rates (Cave 2000).

In South America, T. remus was introduced in 1979 in Venezuela to manage FAW (Ferrer 2001). Hernández et al. (1989) reported 60-83\% FAW egg parasitism in 
maize after three weekly releases of 15,000 adults of $T$. remus. This parasitism level was observed at a distance of 2000 to $2200 \mathrm{~m}$ from the release point with even higher rates $(78-100 \%)$ in eggs closer to the releasing point (from 30 to $1400 \mathrm{~m}$ ).

Telenomus remus parasitism decreases with increasing distance to the release points regardless of crop studied. Dispersion capacity varies from 14.5 to $20.5 \mathrm{~m}$ in 4 days and was highly influenced by local wind speed and direction (Pomari-Fernandes et al. 2018). Thus, the parasitism (\%) and T. remus dispersion observed by Hernández et al. (1989) is probably due to different generations of the parasitoid.

In some other countries of South America, inundative field releases of $T$. remus showed around $80 \%$ parasitism such as in Colombia (García-Roa et al. 2002), Guyana and Suriname, resulting in T. remus establishment in those countries (Cock 1985; Yaseen et al. 1981). In contrast to the mostly successful results reported in this section so far, a field trial established in Brazil during 2008 in maize recorded only a poor effect of $T$. remus on FAW outbreaks. Around 200,000 T. remus were released per hectare but did not increase FAW mortality compared to the control (Varella et al. 2015). Although T. remus was first introduced in Brazil over 35 years ago, its natural occurrences had not been reported until a recent collection of a Telenomus species alerted us to the presence of T. remus in the field in Brazilian agroecosystens (Wengrat et al. 2021).

Those contrasting results may be due to the strain used, and possibly a deterioration of parasitoid colony quality, coming from the Maize and Sorghum Research Center (Embrapa Maize and Sorghum-Sete Lagoas, Minas Gerais, Brazil) where T. remus colony had been kept using FAW eggs under laboratory conditions for more than 20 years. Telenomus remus from this colony had a lifetime fecundity of only 35.7 FAW eggs (Bueno et al. 2010), considerably less than found in other studies (Pomari et al. 2013b; Bueno et al. 2014, see Table 2) which used parasitoids originally collected in Ecuador in 1986 and grown at the parasitoid rearing facilities of ESALQ/USP (Luiz de Queiroz College of Agriculture/University of São Paulo). In addition, Varella et al. (2015) released T. remus in the pupal stage while the other previously mentioned successful field reports released T. remus adults already fed with honey.

\section{Telenomus remus release strategies}

As shown above, $T$. remus has potential as an augmentative biological control agent for the management of Spodoptera spp. However, challenges to be still addressed include: (i) the number (density) of parasitoids released; (ii) the best parasitoid release strategy considering dispersion, release frequency, predation, best timing of release, pest density and climatic conditions at the time of release, and (iii) interactions with other grower's management practices used in the field such as the use of chemical insecticides (King et al. 1985; Smith et al. 1986; Pinto and Parra 2002; Parra 2014).

(i) number of parasitoids released: Detailed information about the effect of numbers of T. remus released in the field is scarce in the literature. In Venezuela, the number of $T$. remus to be released has been estimated based on cost-benefit ratios. Based on field work conducted in various Venezuela States, the release of between approximately 4500 (Yaracuy State) to approximately 9000 (Lara State) parasitoids per hectare was considered most costeffective (Ferrer 2001). This total number of parasitoids to be released in one hectare vary in different regions according to pest infestation rate, crop development stage, among other factors. Even in Venezuela other parasitoid numbers were used by different authors. Hernández et al. (1989) successfully released T. remus at early FAW infestation levels in maize fields in the country. Authors applied 5000 T. remus adults per ha of maize at vegetative stage during three consecutive weeks starting when the germination of the plants occur and resulting in parasitism levels of between 60 and 100\% depending on distance from release points and days after release. Still in Venezuela, optimal FAW control levels were recorded after releasing 40,000-60,000 wasps in maize fields during the season (Linares 1998). Adults were released from $750 \mathrm{ml}$ plastic containers with honey droplets on their walls and using 10,000-15,000 parasitoids per release point, which means four release points per ha.

Differently, Gutierrez-Martinez et al. (2012) reported that the release of 12,000 to 15,000 parasitoids per hectare triggered $36-100 \%$ of parasitism in FAW eggs in Mexico. Ivan et al. (2016) evaluated the necessary number of parasitoids to be released to reduce the damage caused by FAW to maize in Brazil and concluded that releasing 20,000 wasps per hectare for three consecutive weeks was sufficient to reduce the crop damage. Also in Brazil, Figueiredo et al. (2002) recommend the release of 9 to 12 females of $T$. remus per $\mathrm{m}^{2}$ (90,000-120,000/ha), which resulted in 72.4 and $82.8 \%$ parasitism of FAW eggs, respectively. Rezende et al. (2016) reported that releasing 20,000 parasitoids of $T$. remus per ha was efficient to reduce the FAW damage to 3 using a damage score of $0-9$.

The release of $T$. remus numbers divided in different consecutive weeks is usually recommended because adults of $T$. remus have a short longevity of between 4 to 7 days, when they carry $80 \%$ of their lifetime parasitism (Pomari et al. 2013b) and have the greatest parasitism capacity in FAW eggs from 24 to $48 \mathrm{~h}$ of embryonic 
development, with negligible parasitism in eggs of $72 \mathrm{~h}$ (Queiroz et al. 2019). Considering a field situation with the presence of FAW on different development stages, the release of the parasitoid numbers divided in 3 or 4 weeks in the field is a way to improve the matching of 4-7-day-old T. remus adults with host eggs of 1 or 2 days, which is essential for the successful management of FAW using T. remus (Fonseca et al. 2016).

As previously mentioned, the total number of parasitoids to be released per hectare differs from country to country and not always the studies present the percentage of parasitism obtained, or the criteria used for the best moment to initiate the parasitoids releases and the frequency applied. The most common numbers vary between 5000 and 50,000 parasitoids/ha and season. Table 3 presents the number of parasitoids released in different countries in Latin America, the frequency of parasitoids releases and the percentage of parasitism when reported. More recently, Wengrat et al. (2021) suggested that reintroductions of natural populations of T. remus from different geographical origins may be an efficient tactic for classical and augmentative biological control of S. frugiperda in different parts of the world, increasing the changes of parasitoid establishment in the environment as those authors observed in Brazil.

(ii) parasitoid release strategy: In general, T. remus can be released as pupae inside parasitized eggs or as adults. Most studies reviewed here released adults, already fed with honey and thereby increasing parasitoid chances to succeed. The methodology to release $T$. remus established in Venezuela in the 1990s consists of walking through the rows of maize with plastic cups containing newly emerged parasitoids and opening the containers at random near the corn plants. The initiation of parasitoid releases is recommended during the crop's germination stage (García-Roa 1999), followed by 3-4 consecutive applications every 7 days or up to 5 applications based on monitoring of FAW incidence (Hernández et al. 1989; García-Roa 1999). In terms of the number of releasing points of $T$. remus, some technical documents recommend the use of 12-14 points, by opening the containers with the parasitoids for a few seconds looking forward to ensure a good distribution of the parasitoids at the field level (Gobierno de la Libertad 2012). However, other studies reported the use of only three or four releasing points per ha (Figueiredo et al. 2002; F. Ferrer, personal communication) leaving the plastic containers in a centralized area of the field for $24 \mathrm{~h}$ to allow the exit of all parasitoids (Varella et al. 2015).

In Brazil, the pupa stage has been preferred by the biological control industry due to the ease of mechanization of the release process in the field, reducing labour and operating costs (Pinto and Parra 2002). Eggs of parasitized hosts, containing parasitoid pupae inside, can be easily and homogeneously sprayed onto the crop using drones. This kind of release has already been adopted in Brazil for other parasitoid species such as Trichogramma spp.

Differently from Trichogramma spp. where pupae can be released only a few hours before parasitoid emergence, the release of $T$. remus pupae is more complicated since males emerge $24 \mathrm{~h}$ before females. Then $T$. remus pupae exposed in the field one or two days before the emergence of adults may face high mortality due to the action of predators (ants, lacewings, ladybugs, among others) (Cave 2000; Parra 2014). Therefore, the use of adults already fed with honey should be considered as a good alternative option, despite its release mechanization process still need to be developed and tested on large scale.

Besides predation, the released parasitoids must also survive climate conditions (rainfall and temperature) to which they will be exposed. Adverse climate conditions

Table 3 Total Number of Telenomus remus per hectare released in maize in different countries in Latin America, frequency of releases and percentage of parasitism of FAW eggs

\begin{tabular}{lllll}
\hline Country & Number/ha and season & Frequency of releases & Parasitism (\%) & References \\
\hline Venezuela & 5000 & 3 at weekly intervals & $60-100$ & Hernandez et al. (1989) \\
Venezuela & $4433-9260$ & 4 at weekly intervals & $70-100$ & Ferrer (2001) \\
Venezuela & $40,000-60,000$ & 10 at weekly intervals & No information & Linares (1998) \\
Honduras & $35,000-50,000$ & Weekly & $65-92$ & Cave and Acosta (1999) \\
Brazil & 60,000 & No information & No information & Cruz (2007) \\
Brazil & $90,000-120,000$ & One application & $72.4-82.8$ & Figueiredo et al. (2002) \\
Brazil & 20,000 & 3 at weekly intervals & No information & Rezende and Silva et al. (2016) \\
Brazil & 20,000 & 3 at weekly intervals & No information & Ivan et al. (2016) \\
Brazil & $100,000-200,000$ & One application & $9-14$ & Salazar-Mendoza et al. (2020) \\
Brazil & 200,000 & One application & $1.4-9$ & Varella et al. (2015) \\
Colombia & 33,000 & 4-5 applications & 80 & García-Roa (1999) \\
\hline
\end{tabular}


can constitute an important mortality factor, in particular when egg parasitoids are released as immobile pupae in the field, unable to seek shelter to protect themselves.

Among climate conditions as abiotic factors of insect mortality, temperature is noteworthy (Frazer and Mcgregor 1992), as it directly affects parasitoid emergence (Braz et al. 2021). Based on that, Grande et al. (2021) suggested that adults of T. remus should be released early in the morning. This strategy may also allow adults to find shelter from high temperatures during warmer times of the day.

In addition, releasing T. remus adults late in the evening could be a mistake because the parasitoid is inactive during the night (Grande et al. 2021). The longer adult parasitoids are exposed in the field, the greater the chances they may be injured by pesticides (Carmo et al. 2010), climate (Bueno et al. 2008; Pomari et al. 2012) or other biotic or abiotic factors that can increase adult mortality and reduce their efficacy in controlling eggs of target pests (Cave 2000; Ferrer 2001).

(iii) interaction with pesticides: Despite the biological control potential of T. remus against FAW, chemical control might still be needed to control FAW outbreaks, or against other pests (Bueno et al. 2021). Thus, to understand the threats that pesticides pose for T. remus as well as the possible uses of selective pesticide is essential to allow both, chemical and biological control, to be used in combination within IPM programs (Torres and Bueno 2018). Recently conducted studies have demonstrated that numerous biopesticides are available for FAW control, some of which are showing good efficacy (Babendreier et al. 2020b; Guo et al. 2020; Bateman et al. 2021). These are generally harmless to parasitoids and some have been explicitly tested against T. remus (Amaro et al. 2018; Silva et al. 2016). However, even among the synthetic insecticides, active ingredients belonging to the group of Insect Growth Regulators (IGRs), such as diflubenzuron, flufenoxuron and methoxyfenozide, are relatively more selective and viable options to control lepidopteran pests in conjunction with $T$. remus whenever necessary. In contrast, pyrethroids such as bifenthrin, gamma-cyhalothrin or beta-cyfluthrin, organophosphates such as chlorpyrifos and acephate, and also spinosad were among the most harmful pesticides to the parasitoid, especially to adults, which is generally the most susceptible parasitoid stage (Hassan et al. 1985; Carmo et al. 2009, 2010). These broad-spectrum insecticides should be strongly avoided in fields around a couple of weeks before and after T. remus releases. Where stink bugs or chrysomelids need to be controlled, pyrethroids or organophosphates may be preferred by farmers, posing a challenge for T. remus preservation. Fungicides and herbicides are generally less harmful to $T$. remus when compared to insecticides (Stecca et al. 2016). However, they also should be only applied when necessary because products such as epoxyconazole or clomazone can still harm T. remus (Carmo et al. 2009, 2010).

\section{Experience using T. remus in Africa and Asia}

FAW was recorded for the first time in West Africa in early 2016 (Goergen et al. 2016; Cock et al. 2017) causing a significant loss on maize production soon after arrival on the continent (Day et al. 2017). In Africa, growers also responded by using lots of pesticides after arrival of FAW, threatening farmer's health as well as the sustainability of maize cropping systems, traditionally done with low inputs (Tambo et al. 2020). Targeting other armyworms, classical biological control involving T. remus has been initiated in Africa. It was released in the Cape Verde Islands in the early 1980s, but its establishment has not been confirmed. When the FAW invaded Africa in 2016, this option was discussed again but interestingly this egg parasitoid was found to be already present on the continent (Kenis et al. 2019). A recent survey found $T$. remus to be present in most regions of Benin and Ghana (Agboyi et al. 2020). Similarly, T. remus was found in Southern parts of Asia, with FAW egg mass parasitism rates of $30 \%$ already in the first season after pest arrival in China (Liao et al. 2019). Like for classical biological control, also augmentative approaches using T. remus have been put forward or already tested recently in Africa. Laminou et al. (2020) released 62,500 T. remus per ha in sorghum fields in Niger in relatively small plots of $200 \mathrm{~m}^{2}$ and using sentinel eggs. Combined results for the two seasons, showed that $64 \%$ eggs were parasitized under these conditions while $<10 \%$ were observed in control fields. In field release studies in Ghana, three releases of 30,000 T. remus per ha were conducted in maize plots of $0.5 \mathrm{ha}$ in the major and minor rainy season respectively (Agboyi et al. 2021). Egg mass parasitism reached 33\% in the $T$. remus release plot in the major rainy season while $72-100 \%$ of egg masses were parasitized in the minor rainy season during which pest densities were much lower. However, no significant difference in egg mass parasitism was found between release and no-release plots, despite considerable distances of $150-400 \mathrm{~m}$ between them.

\section{Conclusions and recommendations}

In summary, no ready-to-use package is available to advise farmers in using $T$. remus against FAW and related pests. Further studies are urgently needed to precisely determine optimal release rates, release times and frequencies, number of release points, the best stage and device for releases and other aspects such as 
how large the fields should be to achieve efficient pest control. There is unfortunately surprisingly few data on the real effect mass releases of $T$. remus have on reducing plant damage and increasing yield, but often high egg parasitism rates together with long-term evidence from Venezuela suggest that $T$. remus has indeed high potential to successfully suppress FAW and related pests.

It needs to be stressed that most of the results reviewed here are based on T. remus reared from Spodoptera hosts. From these, relatively large and fecund wasps can be produced but also at relatively high costs, when compared to the rearing of Trichogramma spp. This points to the conclusion that, if biological control of FAW and related pests with T. remus should become a viable option, release rates may need to be more closely to rates used in the 1990s in Venezuela, i.e. rates of about 5000-10,000 wasps per ha and season, unless major breakthroughs with cheaper mass production of the parasitoid are achieved. This may be based on 3-4 releases of 2000-2500 wasps each, starting after FAW has shown up (usually around a week after maize emergence in the field).

A major point of concern is to what extent releases at one site can also have an effect on larger areas during the season. Recent findings from Ghana (Agboyi et al. 2021) are in line with studies from the Americas (Hernández et al. 1989) indicating that dispersal of T. remus throughout the season is high, and that a small number of release points per ha $(<5)$ may be sufficient. These studies further suggest that releases for individual smallholder farmers owning little land may be inefficient, but on the other hand that regional approaches could work very well. Similar to probably all other biological control agents in field crops, the use of T. remus will best be done as a part of an IPM program, avoiding broadspectrum insecticides in release fields. Both quality control of the mass reared parasitoid and an optimized, cost-efficient release strategy is crucial to a successful pest management.

When considering the use of biological control agents, it is always necessary to include an assessment of possible risks for non-target effects, particularly for exotic species (De Clercq et al. 2011). In most of those countries where T. remus may be considered for release in the future, the parasitoid has been found to be present, e.g. China, India, Australia and several African countries, so cannot be considered exotic there. However, in regions where $T$. remus is not known from, its status should be carefully evaluated and appropriate risk assessment procedures followed. Altogether, T. remus releases may be having high prospects for contributing to FAW management in newly invaded areas though still challenges exist that would require further research.

\section{Acknowledgements}

The authors thank Embrapa Soja, CABI Brazil and CABI Switzerland for their support. Authors also gratefully acknowledge the core financial support from the member countries (and lead agencies) of CABI (an international intergovernmental organization), including the United Kingdom (Department for International Development), China (Chinese Ministry of Agriculture), Australia (Australian Centre for International Agricultural Research), Canada (Agriculture and Agri-Food Canada), the Netherlands (Directorate-General for International Cooperation), and Switzerland (Swiss Agency for Development and Cooperation). See https://www.cabi.org/what-we-do/how-we-work/cabi-donors-andpartners/ for full details.

\section{Authors' contributions}

YCC, DB, FFW, CV-F and AFB contributed to the data review and wrote the paper. All authors read and approved the final manuscript.

Funding

Not applicable.

Availability of data and materials

No applicable.

\section{Declarations}

Ethics approval and consent to participate

Not applicable.

\section{Consent for publication}

Authors give CABI Agriculture and Bioscience Journal full consent for publication.

\section{Competing interests}

The authors declare no competing interests.

\section{Author details}

${ }^{1}$ CABI-UNESP-FEPAF, Rua José Barbosa de Barros, 1780, Botucatu, SP 18610-307, Brazil. 2 CABl's Swiss Centre, Rue des Grillons 1, 2800 Delémont, Switzerland. ${ }^{3}$ Independent Entomologist Advisor, Barquisimeto, Lara, Venezuela. ${ }^{4}$ Faculty of Agricultural Sciences, Technical University of Ambato, Campus Querochaca, Cevallos, Tungurahua, Ecuador. ${ }^{5}$ Embrapa Soja, Rodovia Carlos João Strass - Distrito de Warta, Londrina, Paraná 86001-970, Brazil.

Received: 13 July 2021 Accepted: 24 December 2021

Published online: 15 January 2022

\section{References}

Agboyi LK, Goergen G, Beseh P, Mensah SA, Clottey VA, Glikpo R, Buddie A, Cafà G, Offord L, Day R, Rwomushana I, Kenis M. Parasitoid complex of fall armyworm, Spodoptera frugiperda, in Ghana and Benin. Insects. 2020. https://doi.org/10.3390/insects11020068.

Agboyi LK, Layodé BFR, Fening KO, Beseh P, Clottey VA, Day RK, Kenis M, Babendreier D. Assessing the potential of inoculative field releases of Telenomus remus to control Spodoptera frugiperda in Ghana. Insects. 2021;12(8):665

Amaro JT, Bueno AF, Neves PMOJ, Silva DM, Pomari-Fernandes A, Favetti BM. Selectivity of different biological products to the egg parasitoid Telenomus remus (Hymenoptera: Platygastridae). Rev Bras Entomol. 2018;62:195-7. https://doi.org/10.1016/j.rbe.2018.04.003.

Ansari MA, Pawar AD, Kumar DA. Possibility for biocontrol of tropical armyworm, Spodoptera litura (Lepidoptera: Noctuidae) on potato. Plant Prot Bull. 1992;44:27-31.

Babendreier D, Agboyi LK, Beseh P, Osae M, Nboyine J, Ofori SEK, Frimpong OJ, Clottey VA, Kenis K. The efficacy of alternative, environmentally friendly plant protection measures for control of fall armyworm, Spodoptera frugiperda, in maize. Insects. 2020b;11:240. https://doi.org/10.3390/ insects 11040240.

Babendreier D, Hou M, Tang R, Zhang F, Vongsabouth T, Win KK, Kang M, Peng H, Song K, Annamalai S, Horgan FG. Biological control of lepidopteran 
pests in rice: a multi-nation case study from Asia. J Integr Pest Manag. 2020a; 11(1):5.

Bateman ML, Day RK, Rwomushana I, Subramanian S, Wilson K, Babendreier D, Luke B, Edgington S. Updated assessment of potential biopesticide options for managing fall armyworm (Spodoptera frugiperda) in Africa. J Appl Entomol. 2021;145(5):384-93.

Bortolotto OC, Pomari-Fernandes A, Bueno RCOF, Bueno AF, Kruz YKS, Queiroz AP, Sanzovo A, Ferreira RB. The use of soybean integrated pest management in Brazil: a review. Agron Sci Biotechnol. 2015:1:25-32.

Braz ÉC, Bueno AF, Colombo FC, Queiroz AP. Temperature Impact on Telenomus podisi emergence in field releases of unprotected and encapsulated parasitoid pupae. Neotrop Entomol. 2021;50(3):462-9. https://doi.org/ 10.1007/s13744-021-00857-3.

Brown E, Dewhurst C. The genus Spodoptera (Lepidoptera, Noctuidae) in Africa and the Near East. B Entomol Res. 1975;65:221-62. https://doi.org/10. $1017 / 50007485300005939$.

Bruce A, Schulthess F, Mueke J. Host acceptance, suitability, and effects of host deprivation on the West African egg parasitoid Telenomus isis (Hymenoptera: Scelionidae) reared on east African stemborers under varying temperature and relative humidity regimens. Environ Entomol. 2009:38:904-19. https://doi.org/10.1603/022.038.0345.

Bueno RCOF, Bueno AF, Carneiro TR, Pratissoli D, Fernandes OA. Biology and thermal requirements of Telenomus remus Nixon (Hymenoptera: Scelionidae) reared on fall armyworm Spodoptera frugiperda (J. E. Smith) (Lepidoptera: Noctuidae) eggs. Cienc Rural. 2008;38:1-6. https://doi. org/10.1590/S0103-84782008000100001

Bueno RCOF, Carneiro TR, Bueno AF, Pratissoli D, Fernandes OA, Vieira SS. Parasitism capacity of Telenomus remus Nixon (Hymenoptera: Scelionidae) on Spodoptera frugiperda (Smith) (Lepidoptera: Noctuidae) eggs. Braz Arch Biol Techn. 2010;53:1339. https://doi.org/10.1590/S1516-89132 010000100017.

Bueno RCOF, Bueno AF, Moscardi F, Parra JR, Hoffmann-Campo CB. Lepidopteran larvae consumption of soybean foliage: basis for developing multiple-species economic thresholds for pest management decisions. Pest Manag Sci. 2011;67:170-4. https://doi.org/10.1002/ps.2047.

Bueno RCOF, Bueno AF, Xavier MFC, Carvalho MM. Telenomus remus (Hymenoptera: Platygastridae) parasitism on eggs of Anticarsia gemmatalis (Lepidoptera: Eribidae) compared with its natural host Spodoptera frugiperda (Lepidoptera: Noctuidae). Ann Entomol Soc Am. 2014;107:799808. https://doi.org/10.1603/AN14002.

Bueno AF, Panizzi AR, Hunt TE, Dourado PM, Pitta RM, Gonçalves J. Challenges for adoption of integrated pest management (IPM): the soybean example. Neotrop Entomol. 2021;50:5-20. https://doi.org/10.1007/ s13744-020-00792-9.

Cabezas MF, Nava DE, Geissler LO, Melo M, Garcia MS, Krüger R. Development and leaf consumption by Spodoptera cosmioides (Walker) (Lepidoptera: Noctuidae) reared on leaves of agroenergy crops. Neotrop Entomol. 2013;42(6):588-94. https://doi.org/10.1007/s13744-013-0169-6.

Carmo EL, Bueno AF, Bueno RCOF, Vieira SS, Gobbi AL, Vasco FR. Seletividade de diferentes agrotóxicos usados na cultura da soja ao parasitoide de ovos Telenomus remus. Cienc Rural. 2009;39:2293-300. https://doi.org/ 10.1590/S0103-84782009005000188.

Carmo EL, Bueno AF, Bueno RCOF. Pesticide selectivity for the insect egg parasitoid Telenomus remus. Biocontrol. 2010;55:455-64. https://doi.org/ 10.1007/s10526-010-9269-y.

Carvalho RA, Omoto C, Field LM, Williamson MS, Bass C. Investigating the molecular mechanisms of organophosphate and pyrethroid resistance in the fall armyworm Spodoptera frugiperda. PLoS ONE. 2013;8: e62268. https://doi.org/10.1371/journal.pone.0062268.

Cave RD. Biology, ecology and use in pest management of Telenomus remus. Biocontrol News Inform. 2000;21:21-6.

Cave RD, Acosta NM. Telenomus remus Nixon: um parasitoide en el control biológico del gusano cogollero Spodoptera frugiperda (Smith). Ceiba. 1999:40:215-27.

Cock MJW, Beseh PK, Buddie AG, Cafá G, Crozier J. Molecular methods to detect Spodoptera frugiperda in Ghana, and implications for monitoring the spread of invasive species in developing countries. Sci Rep. 2017;7(4103):10. https://doi.org/10.1038/s41598-017-04238-y.

Cock MJW. A review of biological control of pests in the Commonwealth Caribbean and Bermuda up to 1982. Farnham Royal: Commonwealth Institute of Biological Control Technical Communication; 1985.
Cruz I. Controle biológico de pragas na cultura de milho para a produção de conservas (minimilho) por meio de parasitoides e predadores. Embrapa milho e sorgo, Circular Técnica 91. 2007; 16p.

Day R, Abrahams P, Bateman M, Beale T, Clottey V, Cock M, Colmenarez Y, Corniani N, Early R, Godwin J, Gomez J, Gonzalez Moreno P, Murphy ST, Oppong-Mensah B, Phiri N, Pratt C, Silvestri S, Witt A. Fall Armyworm: Impacts and Implications for Africa. Outlook Pest Manag. 2017. https:// doi.org/10.1564/v28_oct_02.

De Clercq P, Mason PG, Babendreier D. Benefits and risks of exotic biological control agents. Biocontrol. 2011;56(4):681-98. https://doi.org/10.1007/ s10526-011-9372-8.

Denis D, Pierre JS, van Baaren J, van Alphen JJ. How temperature and habitat quality affect parasitoid lifetime reproductive success - a simulation study. Ecol Model. 2011;222:1604-13. https://doi.org/10.1016/j.ecolm odel.2011.02.023.

Diez-Rodriguez Gl, Omoto C. Herança da resistência de Spodoptera frugiperda (J. E. Smith) (Lepidoptera: Noctuidae) à lambda-cialotrina. Neotrop Entomol. 2001;30:311-6. https://doi.org/10.1590/S1519-566X200100 0200016.

Ferrer F. Biological of agricultural insect pest in Venezuela; advances, achievements, and future perspectives. Biocontrol News Inform. 2001;22:67-74.

Ferrer F. Biological control of agricultural pests in Venezuela: Historical achievements of Servicio Biológico (SERVBIO). Revista de Ciencias Ambientales. 2021;55(1):327-44. https://doi.org/10.15359/rca.55-1.16.

Figueiredo MLC, Della Lucia TMC, Cruz I. Controle integrado de Spodoptera frugiperda (Smith \& Aboth) utilizando-se do parasitoide Telenomus remus Nixon. Pesqui Agropecu Bras. 1999;34:1975-82. https://doi.org/10.1590/ S0100-204X1999001100001.

Figueiredo MLC, Lucia TMCD, Cruz I. Effect of Telenomus remus Nixon (Hymenoptera: Scelionidae) density on control of Spodoptera frugiperda (Smith) (Lepidoptera: Noctuidae) egg masses upon release in a maize field. Revista Brasileira de Milho e Sorgo. 2002;1 (2):12-9. https://doi.org/ 10.18512/1980-6477/rbms.v1n2p12-19.

Fonseca IIA, Rezende SK, Loboschi DL, Pires AL, Pereira SSAJ, Pinto SA. Número de liberações de Telenomus remus no controle de ovos de Spodoptera frugiperda em milho de segunda safra. XXXI Congresso Nacional de Milho e Sorgo. 2016. p.289-293.

Frazer BD, Mcgregor RR. Temperature-dependent survival and hatching rate of eggs of seven species of Coccinellidae. Can Entomol. 1992;124:305-12. https://doi.org/10.4039/Ent124305-2.

Fuentes F, Ferrer F, Salas J. Reseña Histórica del Control, Biológico en Centroamérica y el Caribe. Ed. Académica Española, LAP LAMBERT Academic Publishing GmbH \& Co., Saarbrucken, Germany. 2012;200 p.

García-Roa F, Mosquera EMT, Vargas SCA, Rojas AL. Control biológico, microbiológico y físico de Spodoptera frugiperda (Lepidoptera: Noctuidae), plaga del maíz y otros cultivos en Colombia. Rev Colomb Entomol. 2002;28:53-60.

García-Roa F. Control biológico, microbiológico y físico de Spodoptera frugiperda, plaga de maíz y otros cultivos en Colombia. Corpoica. 1999. 18 p. Available at: https://www.cabi.org/wp-content/uploads/Garcia-1999IPM-of-Spodoptera-frugiperda.pdf. Accessed: june 25, 2021

Gautum RD. Influence of different noctuid hosts on the parasitisation by Telenomus remus Nixon (Scelionidae: Hymenoptera). J Entomol Res. 1986;10:70-3.

Gautum RD, Gupta T. Mass-multiplication of the cutworm, Agrotis spinifera (Hübner). Ann Agric Res. 1994;15:64-9.

Glober JM. The effect of Ricinus communis on larval behaviour and midgut microbe communities of Spodoptera frugiperda (Lepidoptera: Noctuidae). Dissertation thesis, North-West University. 2019. 90 p.

Gobierno Regional La Libertad. Proyecto Especial Chavimochic: laboratorio de insectos benéficos. 2012. http://www.chavimochic.gob.pe/. Available on: http://www.chavimochic.gob.pe/images/boletines/Laboratorio_ Insectos.pdf. Accessed June 30, 2021

Goergen G, Kumar PL, Sankung SB, Togola A, Tamò M. First report of outbreaks of the fall armyworm Spodoptera frugiperda (J E Smith) (Lepidoptera, Noctuidae), a new alien invasive pest in West and Central Africa. PLoS ONE. 2016;11(10): e0165632. https://doi.org/10.1371/journal.pone. 0165632.

Grande MLM, Queiroz AP, Gonçalves J, Hayashida R, Ventura UM, Bueno AF. Impact of environmental variables on parasitism and emergence of 
Trichogramma pretiosum, Telenomus remus and Telenomus podisi. Neotrop Entomol. 2021. https://doi.org/10.1007/s13744-021-00874-2.

Guo J, Wu S, Zhang F, Huang C, He K, Babendreier D, Wang Z. Microbial control of the fall armyworm Spodoptera frugiperda: a review. Biocontrol. 2020;65:1-16.

Gupta M, Pawar AD. Multiplication of Telenomus remus Nixon on Spodoptera litura (Fabricius) reared on artificial diet. J Adv Zool. 1985;6:13-7.

Gutierrez-Martinez A, Tolon-Becerra A, Lastra-Bravo XB. Biological control of Spodoptera frugiperda eggs using Telenomus remus Nixon in maizebean-squash polyculture. Am J Agric Biol Sci. 2012;7:285-92.

Hassan SA, Bigler F, Blaisinger P, Bogenschütz H, Brun J, Chiverton P, Dickler E, Easterbrook MA, Edwards PJ, Englert WD, Firth SL, Huang P, Inglesfield C, Klingauf F, Ku'hner C, Ledieu MS, Naton E, Oomen PA, Overmeer WPJ, Plevoets P, Reboulet JN, Rieckmann W, Samsoe-Petersen L, Shires SW, Staubli A, Stevenson J, Tuset JJ, Vanwetswinkel G, Van Zon AQ. Standard methods to test the side-effects of pesticides on natural enemies of insects and mites developed by the IOBC/WPRS working group 'Pesticides and Beneficial Organisms'. EPPO Bull. 1985;15:214-55. doi: https:// doi.org/10.1111/j.1365-2338.1985.tb00224.x.

Hernández D, Ferrer F, Linares B. Introducción de Telenomus remus Nixon (Hym: Scelionidae) para controlar Spodoptera año (Lep: Noctuidae) en Yaritagua. Venezuela Agron Trop. 1989;39:199-205.

Ivan IAF, Silva KR, Loboschi DL, Araujo Jr LP, Santos AJPS, Pinto SA. Número de liberações de Telenomus remus no controle de ovos de Spodoptera frugiperda em milho de segunda safra. XXXI Congresso Nacional de milho e Sorgo. 2016. Bento Gonçalves, RS, p. 289-293.

Joshi BG, Ramaprasad G, Sitaramaiah S, Sathyanarayana CVV. Some observations on Telenomus remus Nixon, an egg parasite of the tobacco caterpillar, Spodoptera litura (F.). Tobacco Research. 1976;2:17-20.

Kenis M, du Plessis H, Van den Berg J, Ba MN, Goergen G, Kwadjo KE. Telenomus remus, a candidate parasitoid for the biological control of Spodoptera frugiperda in Africa, is already present on the continent. Insects. 2019;10(4):1-10. https://doi.org/10.3390/insects10040092.

King EG, Bull DL, Bouse LF, Philips JR. Introduction: biological control of Heliothis spp. in cotton by augmentative releases of Trichogramma. Southwestern Entomologist. 1985;8:1-10.

Kumar DA, Pawar AD, Divakar BJ. Mass multiplication of Telenomus remus Nixon (Hymenoptera: Scelionidae) on Corcyra cephalonica Stainton (Lepidoptera: Galleridae). J Adv Zool. 1986;7:21-3.

Laminou SA, Ba MN, Karimoune L, Doumma A, Muniappan R. Parasitism of locally recruited egg parasitoids of the fall armyworm in africa. Insects. 2020;11(7):430.

Liao YL, Yang B, Xu MF, Lin W, Wang DS, Chen KW, Chen HY. First report of Telenomus remus parasitizing Spodoptera frugiperda and its field parasitism in southern China. J Hymenoptera Res. 2019;73:95.

Linares B. Farm family rearing of egg parasites in Venezuela. Biocontrol News Inform. 1998;19:76N.

Martínez-Martínez L, Padilla-Cortés E, Jarquón-López R, Sánchez-García JA, Cisneros-Palacios ME. Desempeño del gusano cogollero Spodoptera frugiperda (Smith) (Lepidoptera: Noctuidae) alimentado con maíz e higuerilla. Entomología Mexicana. 2015;2:397-403.

Mihm JA. Técnicas Eficientes para la Crianza Masiva e infestación de insectos, en la Selección de las Plantas Hospedantes para Resistencia al Gusano Cogollero, Spodoptera frugiperda. Centro Internacional de Mejoramiento de Maíz y Trigo, CIMMYT, El Baum, Mexico. 1984; 16 p.

Moralles J, Gallardo JS, Vásquez C, Ríos Y. Patrón de emergencia, longevidad, parasitismo y proporción sexual de Telenomus remus (Hymenoptera: Scelionidae) con relación al cogollero del maíz. Bioagro. 2000;12:47-54.

Mujica N, Whu M. Biological control in Peru. In: van Lenteren JC, Bueno VHP, Luna MG, Colmenarez YC, editors. Biological control in Latin America and the Caribbean: its rich history and bright future. Wallingford: CABl; 2020. p. 369-89.

Nagoshi RN. Can the amount of corn acreage predict fall armyworm (Lepidoptera: Noctuidae) infestation levels in nearby cotton? J Econ Entomol. 2009;102:210-8. https://doi.org/10.1603/029.102.0130.

Naranjo-Guevara N, Santos LAO, Barbosa NCCP, Castro ACMC, Fernandes OA. Long-term mass rearing impacts performance of the egg parasitoid Telenomus remus (Hymenoptera: Platygastridae). J Entomol Sci. 2020;55:69-86. https://doi.org/10.18474/0749-8004-55.1.69.

Norris RF, Caswell-Chen EP, Kogan M. Concepts in integrated pest management. Hoboken: Prentice Hall; 2002. p. 586.
Panizzi AR, Bueno AF, Silva FAC. Insetos que atacam vagens e grãos. In: Hoffmann-Campo CB, Côrrea-Ferreira BS, Moscardi F, editors. Soja: Manejo Integrado de Insetos e outros Artrópodes-Praga. Brasília, DF: Embrapa; 2012. p. 335-420.

Parra JRP. Biological control in Brazil: an overview. Sci Agric. 2014;71:345-55. https://doi.org/10.1590/0103-9016-2014-0167.

Parra JRP, Coelho A Jr. Applied biological control in Brazil: from laboratory assays to field application. J Insect Sci. 2019;19:1-6. https://doi.org/10. 1093/jisesa/iey112.

Parra JRP. Mass rearing of egg parasitoids for biological control programs. In: Consoli F, Parra JRPP, Zucchi R, editors. Egg parasitoids in agroecosystems with emphasis on Trichogramma. Progress in Biological Control, vol 9. Springer, Dordrecht; 2010. p. 325-42; doi: https://doi.org/10.1007/ 978-1-4020-9110-0_10.

Pinto AS, Parra JRP. Liberação de inimigos naturais. In: Parra JRP, Botelho PSM, Corrêa-Ferreira BS, Bento JMS, editors. Controle biológico no Brasil: parasitoides e predadores. Barueri, São Paulo: Manole; 2002. p. 325-42.

Pogue GM. A world revision of the genus Spodoptera Guenée (Lepidoptera: Noctuidae). Memoirs Am Entomol Soc. 2002:43:1-202.

Pomari AF, Bueno AF, Bueno RCOF, Menezes Junior AO. Biological Characteristics and thermal requirements of the biological control agent Telenomus remus (Hymenoptera: Platygastridae) reared on eggs of different species of the genus Spodoptera (Lepidoptera: Noctuidae). Ann Entomol Soc Am. 2012;105:73-81. https://doi.org/10.1603/AN11115.

Pomari AF, Bueno AF, Bueno RCOF, Menezes Junior AO. Telenomus remus Nixon egg parasitization of three species of Spodoptera under different temperatures. Neotrop Entomol. 2013a;42:399-406. https://doi.org/10. 1007/s13744-013-0138-0.

Pomari AF, Bueno AF, Bueno RCOF, Menezes Junior AO, Fonseca ACPF. Releasing number of Telenomus remus (Nixon) (Hymenoptera: Platygastridae) against Spodoptera frugiperda Smith (Lepidoptera: Noctuidae) in corn, cotton and soybean. Cienc Rural. 2013b;43:377-82. https://doi.org/10. 1590/S0103-84782013005000013.

Pomari-Fernandes A, Queiroz AP, Bueno AF, Sanzovo AW, De Bortoli SA. The importance of relative humidity for Telenomus remus (Hymenoptera: Platygastridae) parasitism and development on Corcyra cephalonica (Lepidoptera: Pyralidae) and Spodoptera frugiperda (Lepidoptera: Noctuidae) eggs. Ann Entomol Soc Am. 2014;108:11-7. https://doi.org/ 10.1093/aesa/sau002.

Pomari-Fernandes A, Bueno AF, Queiroz AP, De Bortoli SA. Biological parameters and parasitism capacity of Telenomus remus Nixon (Hymenoptera: Platygastridae) reared on natural and factitious hosts for successive generations. Afr J Agr Res. 2015;10:3225-33. https://doi.org/10.5897/ AJAR2015.10154.

Pomari-Fernandes A, Bueno AF, De Bortoli SA. Size and flight ability of Telenomus remus parasitoids reared on eggs of the factitious host Corcyra cephalonica. Rev Bras Entomol. 2016;60:177-81. https://doi.org/10. 1016/j.rbe.2016.02.004.

Pomari-Fernandes A, Bueno AF, De Bortoli SA, Favetti BM. Dispersal capacity of the egg parasitoid Telenomus remus Nixon (Hymenoptera: Platygastridae) in maize and soybean crops. Biol Control. 2018;126:158-68. https://doi.org/10.1016/j.biocontrol.2018.08.009.

Queiroz AP, Bueno AF, Pomari-Fernandes A, Grande MLM, Bortolloto OC, Silva DM. Low temperature storage of Telenomus remus (Nixon) (Hymenoptera: Platygastridae) and its factitious host Corcyra cephalonica (Stainton) (Lepidoptera: Pyralidae). Neotrop Entomol. 2017a;46:182-92. https://doi.org/10.1007/s13744-016-0442-6.

Queiroz AP, Bueno AF, Pomari-Fernandes A, Grande MLM, Bortolotto OC, Silva DM. Quality control of Telenomus remus (Hymenoptera: Platygastridae) reared on the factitious host Corcyra cephalonica (Lepidoptera: Pyralidae) for successive generations. B Entomol Res. 2017b;107:791-8. https://doi.org/10.1017/S000748531700030X.

Queiroz AP, Favetti BM, Luski PGG, Goncalvez J, Neves PMOJ, Bueno AF. Telenomus remus (Hymenoptera: Platygastridae) parasitism on Spodoptera frugiperda (Lepidoptera: Noctuidae) eggs: different parasitoid and host egg ages. Semin-Cienc Agrar. 2019:40:2933-46. https://doi.org/10. 5433/1679-0359.2019v40n6Supl2p2933.

Ramos-López MA, Pérez GS, Rodríguez-Hernández C, Guevara-Fefer P, Zavala-Sánchez MA. Activity of Ricinus communis (Euphorbiaceae) against Spodoptera frugiperda (Lepidoptera: Noctuidae). Afr J Biotech. 2010;9(9):1359-65. 
Rezende SK, Loboschi DL, Alexandre NO, Carneiro RP, Arroyo BM, Pinto AS. Quantidade liberada de Telenomus remus no controle de ovos de Spodoptera frugiperda em milho de segunda safra. XXXI Congresso Nacional de Milho e Sorgo. 2016. p.308-313. Available at: http://www. abms.org.br/cnms2016_trabalhos/docs/1145.pdf. Accessed: May 20, 2021

Román Suárez DX. Bioensayos de campo y análisis económico de la producción del virus de la poliedrosis nuclear Spodoptera frugiperda. Tegucigalpa, Honduras; Escuela Agrícola Panamericana, El Zamorano, Ing. Agr. thesis, 93 pp.1998.

Rwomushana I., Bateman M, Beale T, Beseh, P, Cameron K, Chiluba M, Tambo J. 2018. Fall Armyworm: Impacts and Implications for Africa; Evidence Note Update, October; Report to DFID; CABI: Wallingford, Oxfordshire, UK, 2018.

Sagar GC, Aastha B, Laxman K. An introduction of fall armyworm (Spodoptera frugiperda) with management strategies: a review paper. Nippon J Insect Sci. 2020;1:1010. https://doi.org/10.46266/njes.1010.

Sankaran T. Natural enemies introduced in recent years for biological control of agricultural pests in India. Indian J Agr Sci. 1974;44:425-33.

Santolamazza-Carbone S, Montserrat PN, Cordero-Rivera A. Egg resorption behaviour by the solitary egg parasitoid Anaphes nitens under natural conditions. Entomol Exp Appl. 2008;127:191-8. https://doi.org/10. 1111/j.1570-7458.2008.00699.x.

Santos-Erazo FE. Uso combinado de VPN Spodoptera frugiperda, Telenomus remus y aplicaciones de azúcar para el control biológico del cogollero, Spodoptera frugiperda, enmaíz. Tegucigalpa, Honduras; Escuela Agrícola Panamericana, El Zamorano, Ing. Agr. thesis, 63 pp.; 1998.

Silva DM, Bueno AF, Andrade K, Stecca CS, Neves PMOJ, Moscardi F. Selectivity of organic compounds to the egg parasitoid Telenomus remus Nixon (Hymenoptera: Plastygastridae). Semin-Cienc Agrar. 2016;37:55-6. https://doi.org/10.5433/1679-0359.2016v37n1p55.

Silva DM, Bueno AF, Andrade K, Stecca CS, Neves PMOJ, Oliveira MCN. Biology and nutrition of Spodoptera frugiperda (Lepidoptera: Noctuidae) fed on different food sources. Sci Agric. 2017;74:18-31. https://doi.org/10. 1590/1678-992x-2015-0160.

Smith SM, Hubbes M, Carrow JR. Factors affecting inundative releases of Trichogramma Ril. against the spruce budworm. J Econ Entomol. 1986;101:29-39.

Song F, Swinton SM. Returns to integrated pest management research and outreach for soybean aphid. J Econ Entomol. 2009;102:2116-25. https:// doi.org/10.1603/029.102.0615.

Salazar-Mendoza P, Rodriguez-Saona C, Fernandes OA. Release density, dispersal capacity, and optimal rearingconditions for Telenomus remus, an egg parasitoid of Spodoptera frugiperda, in maize. Biocontrol Sci Technol 2020. https://doi.org/10.1080/09583157.2020.1776841

Stecca CS, Bueno AF, Pasini A, Silva DM, Filho DMZ. Side-effects of glyphosate to the parasitoid Telenomus remus Nixon (Hymenoptera: Platygastridae). Neotrop Entomol. 2016;45:192-200. https://doi.org/10.1007/ s13744-016-0363-4.

Tambo JA, Kansiime MK, Mugambi I, Rwomushana I, Kenis M, Day RK, Lamontagne-Godwin J. Understanding smallholders'responses to fall armyworm (Spodoptera frugiperda) invasion: evidence from five African countries. Sci Total Environ. 2020;740:140015.

Torres JB, Bueno AF. Conservation biological control using selective insecticides: a valuable tool for IPM. Biol Control. 2018;126:53-64. https://doi. org/10.1016/j.biocontrol.2018.07.012.

van Lenteren JC, Bueno VHP. Augmentative biological control of arthropods in Latin America. Biocontrol. 2003;48:123-39. https://doi.org/10.1023/A: 1022645210394.

van Lenteren JC, Bolckmans K, Köhl J, Ravensberg WJ, Urbaneja A. Biological control using invertebrates and microorganisms: plenty of new opportunities. Biocontrol. 2018;63:39-59. https://doi.org/10.1007/ s10526-017-9801-4.

van Welzen CRL, Waage JK. Adaptative responses to local mate competition by the parasitoid Telenomus remus. Behav Ecol Sociobiol. 1987;21:359-65.

Varella AC, Menezes-Netto AC, Souza Alonso JD, Caixeta DF, Peterson RK, Fernandes AO. Mortality dynamics of Spodoptera frugiperda (Lepidoptera: Noctuidae) immatures in maize. PLoS ONE. 2015;10(6):e0130437.

Vásquez C, Ferrer F, Colmenarez YC, Morales SJ. Biological Control in Venezuela. In: van Lenteren JC, Bueno VHP, Luna MG, Colmenarez YC, editors.
Biological control in Latin America and the Caribbean: its rich history and bright future. Wallingford: CABI; 2020. p. 457-72.

Vieira NF, Pomari-Fernandes A, Lemes AAF, Vacari AM, De Bortoli SA, Bueno AF. Cost of Production of Telenomus remus (Hymenoptera: Platygastridae) Grown in Natural and Alternative Hosts. J Econ Entomol. 2017;1 10:2724-6. https://doi.org/10.1093/jee/tox271.

Waddill VH, Whitcomb WH. Release of Telenomus remus (Hym.: Scelionidae) against Spodoptera frugiperda (Lep.: Noctuidae) in Florida. USA Entomophaga. 1982;27:159-62. https://doi.org/10.1007/BF02375224.

Wengrat APGS, Coelho Junior A, Parra JRP, Takahashi TA, Foerster LA, Corrêa AS, Polaszek A, Johnson NF, Costa VA, Zucchi RA. Integrative taxonomy and phylogeography of Telenomus remus (Scelionidae), with the first record of natural parasitism of Spodoptera spp. in Brazil. Sci Rep. 2021;11:14110. https://doi.org/10.1038/s41598-021-93510-3.

Yaseen M, Bennett FD, Barrow RM. Introduction of exotic parasites for control of Spodoptera frugiperda in Trinidad, the eastern Caribbean and Latin America. In: Braithwaite CWD, Pollard GV, editors. Urgent plant pest and disease problems in the Caribbean. Inter-American Institute for Cooperation on Agriculture, Ocho Rios: Jamaica; 1981. p. 161-71.

\section{Publisher's Note}

Springer Nature remains neutral with regard to jurisdictional claims in published maps and institutional affiliations.

Ready to submit your research? Choose BMC and benefit from:

- fast, convenient online submission

- thorough peer review by experienced researchers in your field

- rapid publication on acceptance

- support for research data, including large and complex data types

- gold Open Access which fosters wider collaboration and increased citations

- maximum visibility for your research: over 100M website views per year

At BMC, research is always in progress.

Learn more biomedcentral.com/submissions 